\title{
Effect of Storage Conditions on the Characteristics and Composition of Fresh Goat Cheese Containing Probiotics
}

\author{
Juni Sumarmono*, Triana Setyawardani and Setya Agus Santosa \\ Department of Animal Science, Jenderal Soedirman University, Purwokerto, Indonesia \\ *Corresponding author email: juni.sumarmono@unsoed.ac.id
}

\begin{abstract}
The objective of this study was to determine the characteristics and composition of soft cheese manufactured from goat milk, which contained probiotic bacteria, and stored at different temperatures for up to 90 days. Soft cheese was manufactured from fresh Indonesian Etawah goat milk, with a mix starter culture containing Lactobacillus casei and Bifidobacterium longum (1:1). Animal rennet was added to facilitate curdling. Fresh cheese produced was wrapped in linen clothes and stored under two different temperature conditions, i.e. high temperature $\left(\mathrm{H}: 13-15^{\circ} \mathrm{C}\right)$ and low temperature $\left(\mathrm{L}: 8-10^{\circ} \mathrm{C}\right)$ for up to 90 days. Results showed that goat cheese was characterized as soft with mild goaty flavor, contained no less than $10^{8} \mathrm{CFU}$ of probiotic lactic acid bacteria, $4.6 \mathrm{pH}$, $0.5 \%$ free fatty acid, $57 \%$ moisture, $15 \%$ crude protein, $22 \%$ total fat and $2.5 \%$ mineral. Cheese underwent dehydration during storage which caused an increase in the relative proportion of protein, fat and mineral. The evolution of cheese's $\mathrm{pH}$, titratable acidity and composition was partly affected by storage temperature. At the end of storage periods (90 days) goat cheese was characterized as semi hard and, on average, contained 1.3-1.5\% titratable acidity, $\mathrm{pH}$ of $4.94-4.95,31.22-37.06 \%$ moisture, $24.59-24.09 \%$ crude protein, $33.51-36.17 \%$ total fat, and $5.64-5.53 \%$ minerals. Cheese stored at high temperature had a slight growth of mold on its surface, which was a normal condition for cheese ripening. In conclusion, acceptable characteristics and composition of probioticcontaining cheese can be manufactured from milk of Indonesian Etawah goats and stored at temperature of $8-10^{\circ} \mathrm{C}$ for 90 days.
\end{abstract}

Keywords: probiotic cheese, goat milk, storage time and temperature

Abstrak. Penelitian telah dilakukan dengan tujuan untuk mempelajari karakteristik dan komposisi keju lunak yang dibuat dari susu kambing, dengan penambahan bakteri probiotik, yang disimpan pada suhu berbeda dan penyimpanan hingga 90 hari. Keju lunak dibuat dari susu kambing peranakan Etawah (Indonesian Etawah) dengan menggunakan kultur starter yang mengandung bakteri probiotik Lactobacillus casei and Bifidobacterium longum (1:1). Renet hewani ditambahkan untuk mempercepat proses penggumpalan dan menghasilkan keju segar. Setiap sampel keju dibungkus dengan kain linen dan disimpan pada suhu tinggi $\left(\mathrm{H}: 13-15^{\circ} \mathrm{C}\right)$ dan rendah $\left(\mathrm{L}: 8-10^{\circ} \mathrm{C}\right)$ hingga 90 hari. Hasil menunjukan, keju susu kambing dicirikan dengan tekstur yang lunak dengan sedikit aroma khas susu kambing, mengandung bakteri probiotik tidak kurang dari $10^{8} \mathrm{CFU} / \mathrm{g}, \mathrm{pH}$ rata-rata 4.6, dan total asam tertitrasi $0,5 \%$. Komposisi keju susu kambing terdiri atas $57 \%$ air, $15 \%$ protein, $22 \%$ lemak dan 2,5\% mineral/abu. Terjadi dehidrasi pada keju akibat penguapan selama penyimpanan yang menyebabkan perubahan komposisi keju, khususnya peningkatan kandungan protein, lemak dan mineral secara proporsional. Perubahan $\mathrm{pH}$, total asam lemak tertitrasi dan komposisi sebagian disumbang oleh suhu penyimpanan. Pada akhir masa penyimpanan ( 90 hari), keju susu kambing memiliki total asam tertitrasi1,3 - 1,5\%, pH of 4,94 - 4,95, 31,22-37,06\% air, 24,59-24,09\% protein kasar, $33,51-36,17 \%$ total lemak, and 5,64 - 5,53\% mineral.. Keju ang disimpan pada suhu tinggi mulai menunjukan pertumbuhan jamur pada bagian permukaan, seuatu yang normal pada proses pemeraman keju. Dapat disimpulkan bahwa keju lunak yang mengandung bakteri probiotik dengan karakteristik dan komposisi yang memadai dapat dibuat dari susu kambing, dengan penyimpanan pada suhu $8-10^{\circ} \mathrm{C}$ selama 90 hari.

Kata kunci: keju probiotik, susu kambing, lama dan suhu penyimpanan

\section{Introduction}

Dairy products, such as cheese and yoghurt, provide essential nutrients and bioactive components. The bioactive components are mostly derived from milk casein, which are released during processing or digestion (Park and Nam, 2015; Egger and Ménard, 2017).
Scientific evidences of the roles of milk bioactive peptides in human body are numerous, including satiating, antihypertensive, antidiabetic, antioxidant, and immunomodulator properties (Nongonierma and FitzGerald, 2015).

During milk-based cheese manufacture, lactic acid bacteria (LAB) play important roles to the 
Juni Sumarmono et al/Animal Production. 21(1):56-63, 2019

Accredited by Kemenristek Dikti No 32a/E/KPT/2017. ISSN 1411-2027

proteolysis of casein, breaking the casein down into smaller peptides such as oligopeptides, dipeptides, and amino acids (Santiago-López et al., 2018).

The production of goat milk in Indonesia is relatively small but its contribution to the total milk production is increasing. Most goat milk is produced by Indonesian Etawah goats, Saanen goats and their crossbreds. Goat milk has unique properties and its nutritional composition differs from cow milk. Processing goat milk into various dairy products, such as cheese, yogurt, concentrated yogurt, and kefir offers an opportunity to prolong shelf life and improve nutritional characteristics (Kumar et al., 2016) (Setyawardani and Sumarmono, 2015; Sumarmono et al., 2015). Goat cheese (fresh) was characterized as having low $\mathrm{pH}$ (3.81-4.0) with fat and protein contents ranged from 4.4 to $17.1 \%$ and 8.3 to $10.3 \%$, respectively (El Galiou et al., 2015). A total of twenty five aromatic compounds were identified in the goat cheese, including alcohols, hydrocarbons, ketones, aldehydes and esters (Bezerra et al., 2017). Fresh goat cheese contained high amount of free fatty acids (3260-3507 mg/ $\mathrm{kg}$ ) with high proportion of oleic, stearic, palmitic, myristic and capric acid (El Galiou et al., 2015)

Previous studies have been addressed to develop probiotic-containing cheeses, including cheddar cheese (Ong and Shah, 2009), fresh cheese (Dantas et al., 2016) and Coalho cheese from goat milk (dos Santos et al., 2012; Bezerra et al., 2017). Incorporation of probiotic lactic acid bacteria (LAB) such as Lactobacillus spp and Bifidobacteria spp during cheesemaking contributes to the nutraceutical properties of cheese (Shiby and Mishra, 2013). Cheeses better deliver probiotics due to relatively high $\mathrm{pH}$ and provide a more favorable environment during storage. Also, the high fat content contributes to the protection of the probiotics in the gastrointestinal tracts (Plessas et al., 2012). Probiotic bacteria and storage conditions affect the flavor in goat cheese, meanwhile the production of volatile compounds increases with time (Bezerra et al., 2017). Proteolytic activity in cheese during storage at $14^{\circ} \mathrm{C}$ was higher than at $4^{\circ} \mathrm{C}$ (González-Olivares et al., 2014).

The objective of this study was to determine the characteristics and composition of soft cheese manufactured from Indonesian Etawah goat milk. The cheese contained probiotic bacteria Lactobacillus casei and Bifidobacteria longum, and stored at two different temperature conditions for up to 90 days.

\section{Materials and Methods}

\section{Preparation of raw materials}

Fresh goat milk was obtained from a local goat farmer in Banyumas District, Central Java, Indonesia and transported to the laboratory in a cool box. A batch pasteurization $\left(63^{\circ} \mathrm{C} ; 30 \mathrm{~min}\right)$ was applied to milk (5.3\% milk fat and $3.7 \%$ crude protein) before cheese manufacture. The probiotic bacteria (Lactobacillus casei and Bifidobacteria longum) were obtained from the Laboratory of Animal Products Technology, Faculty of Animal Science, Jenderal Soedirman University. The bacteria were propagated by growing in $120 \mathrm{~g} / \mathrm{L}$ reconstituted skim milk at $37^{\circ} \mathrm{C}$ for 8 hours.

\section{Fresh cheese manufacture}

Five batches of cheese were manufactured using the standard procedure adapted from basic cheesemaking technology (Johnson and Law, 2010). A mix of probiotic cultures containing equal amount of Lactobacillus casei and Bifidobacteria longum ( $2 \% \mathrm{v} / \mathrm{v}$ ) were added to pasteurized goat milk followed by incubation at $40^{\circ} \mathrm{C}$ for two hours. Animal rennet was added to facilitate curdling. Each batch of cheese produced was divided into two portions and wrapped in linen clothes. One portion of cheese from each batch was stored under high temperature condition $\left(\mathrm{H}: 13-15^{\circ} \mathrm{C}\right)$ and another portion was stored under low temperature condition $\left(\mathrm{L}: 8-10^{\circ} \mathrm{C}\right)$ for up to 90 days. 
Juni Sumarmono et al/Animal Production. 21(1):56-63, 2019

Accredited by Kemenristek Dikti No 32a/E/KPT/2017. ISSN 1411-2027

Measurement of total lactic acid bacteria, $\mathrm{pH}$, titratable acidity and composition

Samples of cheese were collected at day 0 , 30,60 and 90 to determine total $L A B, p H$, titratable acidity and proximate composition. Total LAB was determined following the procedures described by Burn et al. (2008). The $\mathrm{pH}$ of cheese samples was measured with a $\mathrm{pH}$ meter (Hanna Instrument Pty) after calibrating the sensor with standard buffers $\mathrm{pH} 4.0$ and 7.0. Titratable acidity was measured by titrating $10 \mathrm{~g}$ of macerated cheese sample in $10 \mathrm{~mL}$ of distilled water using $\mathrm{NaOH} 0.1 \mathrm{~N}$ standard solution. Grated cheese samples were analyzed in duplicate for proximate composition, i.e. total moisture, crude protein, fat and mineral/ashes (AOAC [Association of Official Analytical Chemists], 2006).

\section{Data analysis}

Descriptive analysis was applied to LAB data. T-test was carried out to analyze $\mathrm{pH}$, free fatty acid content and proximate composition at each stage of sampling $(0,30,60$ and 90 days).

\section{Results and Discussion}

Fresh cheese manufactured from Indonesian Etawa goat milk is characterized as soft, white in color with mild goaty flavor. The cheese underwent various changes during storage at different temperatures (high and low temperatures) reflected in the total lactic acid bacteria (Figure 1), acidity or pH (Figure 2), titratable acidity (Figure 3 ) and proximate composition including moisture, protein, fat and minerals (Table 1). In the fresh form, goat cheese containing probiotic bacteria Lactobacillus casei and Bifidobacteria longum contained no less than $10^{8} \mathrm{CFU}$ of total lactic acid bacteria, $4.6 \mathrm{pH}$ ( $0.54 \%$ total titratable acidity) and composed of $57 \%$ moisture, $15 \%$ crude protein, $22 \%$ total fat and $2.5 \%$ minerals.

Figure 1 shows that total lactic acid bacteria slightly decreased but remained above $10^{7}$ $\mathrm{CFU} / \mathrm{g}$ after 90 days of storage. It indicated that the probiotic lactic acid bacteria in cheese were remain viable, both under high and low temperatures. Therefore, cheese manufactured from goat milk is a good medium for probiotic bacteria. The viability of probiotic bacteria is an important consideration when developing functional food products containing probiotics.

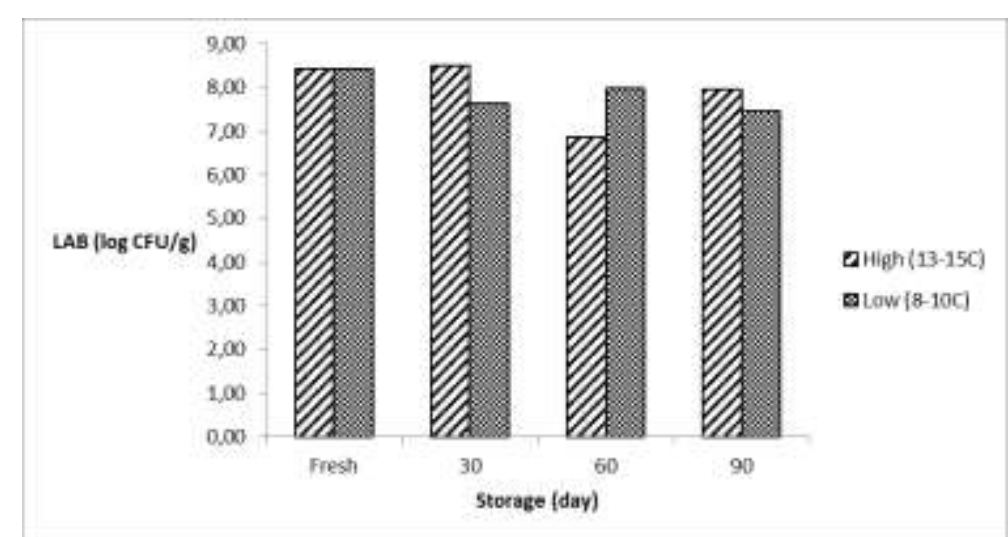

Figure 1. Changes in total lactic acid bacteria (log CFU/g) of goat cheese containing probiotic bacteria during storage (0-90 days) 
Juni Sumarmono et al/Animal Production. 21(1):56-63, 2019

Accredited by Kemenristek Dikti No 32a/E/KPT/2017. ISSN 1411-2027

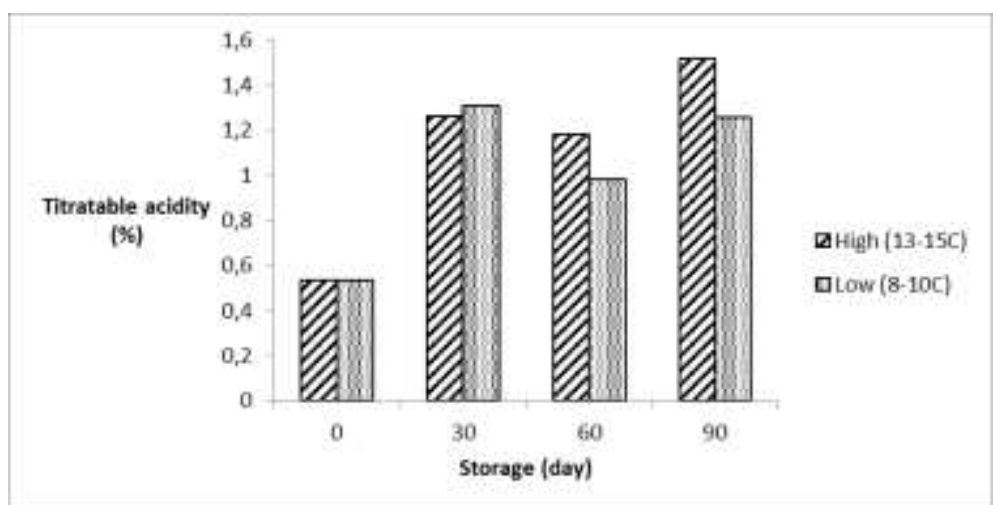

Figure 2. Changes in total titratable acidity of goat cheese containing probiotic bacteria during storage (090 days)

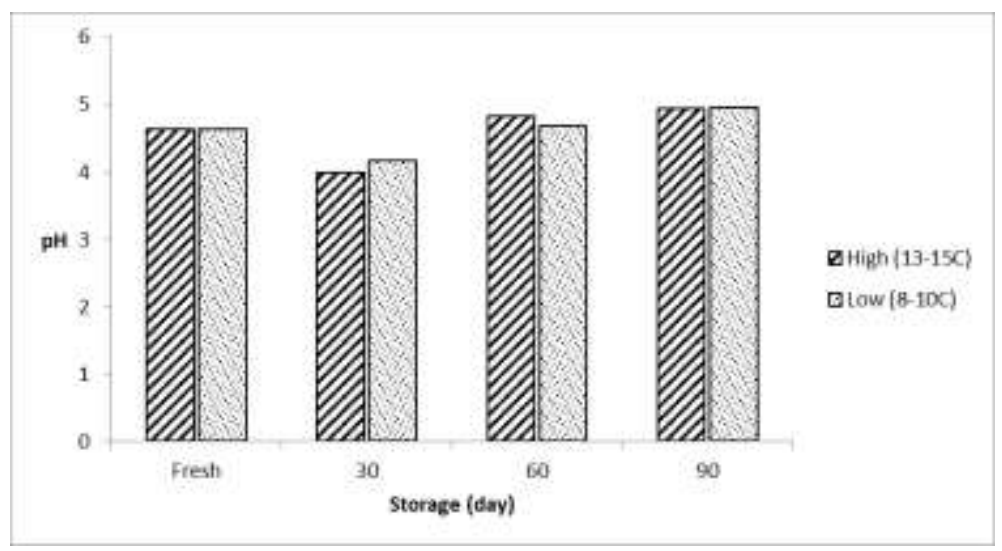

Figure 3. Changes in $\mathrm{pH}$ of goat cheese containing probiotic bacteria during storage (0-90 days)

The titratable acidity of fresh goat cheese was significantly lower $(\mathrm{P}<0.05)$ than that of cheese stored for 30,60, and 90 days, under high and low temperatures (Figure 2). However, no significant effects of storage temperatures on total titratable acidity were observed, although 60 and 90 days of storage saw a slightly lower titratable acidity in goat cheese stored at low compared to high temperature.

During the storage, goat cheese $\mathrm{pH}$ only underwent slight changes; $\mathrm{pH}$ tended to increase from day 30. Differences in storage temperatures did not significantly $(P>0.05)$ affect $\mathrm{pH}$. Maintaining cheese at low $\mathrm{pH}$ is very important because $\mathrm{pH}$ prevents the growth of spoilage bacteria.

As shown in Table 1, the composition of goat cheese containing probiotic bacteria changes significantly during the storage. The moisture contents of the cheese consistently decreased, which affects the protein, fat and mineral contents proportionately. The overall storage temperatures significantly affected $(P<0.05)$ goat cheese composition. Goat cheese stored at low and high temperatures saw a moisture content decreased from $56.9 \%$ to $32.22 \%$ and $37.06 \%$, respectively, while other properties increased, namely total fat content $(22.3 \%$ to $36.17 \%$ and $33.51 \%)$, total protein content (15.98\% to $24.59 \%$ and $24.09 \%$ ), and mineral content (2.5\% to $5.64 \%$ and $5.53 \%$ ).

At the end of storage periods ( 90 days), goat cheese was characterized as semi hard on its surface, yellowish in color and, on average, contained $1.3-1.5 \%$ titratable acidity, 4.94-4.95 $\mathrm{pH}, 31.22-37.06 \%$ moisture, $24.59-24.09 \%$ crude protein, $33.51-36.17 \%$ total fat, and $5.64-5.53 \%$ 
Juni Sumarmono et al/Animal Production. 21(1):56-63, 2019

Accredited by Kemenristek Dikti No 32a/E/KPT/2017. ISSN 1411-2027

minerals. In addition, cheese stored at high

surface, which is a normal phenomenon during temperature has a slight growth of mold at its

cheese ripening.

Table 1. Changes in proximate composition of goat cheese during storage (0-90 days) under different temperature conditions

\begin{tabular}{llll}
\hline Composition & Storage Time (d) & Low (8-10C) & High (13-15C) \\
\hline Moisture (\%) & 0 & 56.96 & 56.96 \\
& 30 & $50.78^{\mathrm{a}}$ & $46.83^{\mathrm{b}}$ \\
& 60 & 48.47 & 46.32 \\
Total fat (\%) & 90 & $31.22^{\mathrm{a}}$ & $37.06^{\mathrm{b}}$ \\
& 0 & 22.03 & 22.03 \\
& 30 & $21.98^{\mathrm{a}}$ & $26.30^{\mathrm{b}}$ \\
& 60 & $22.12^{\mathrm{a}}$ & $30.70^{\mathrm{b}}$ \\
Crude protein (\%) & 90 & $36.17^{\mathrm{a}}$ & $33.51^{\mathrm{b}}$ \\
& 0 & 15.98 & 15.98 \\
& 30 & 17.01 & 18.12 \\
Ash (\%) & 60 & $19.07^{\mathrm{a}}$ & $22.28^{\mathrm{b}}$ \\
& 90 & 24.59 & 24.09 \\
& 0 & 2.50 & 2.50 \\
& 30 & 3.03 & 3.87 \\
& 60 & $3.64^{\mathrm{a}}$ & $5.02^{\mathrm{b}}$ \\
\hline
\end{tabular}

Means in the same row with different superscript differ significantly $(P>0.05)$

The results showed that characteristics and composition of goat cheese containing probiotic lactic acid bacteria changed during high and low temperature storage. The changes can be attributed to the biochemical processes in cheese, and also to the dehydration during storage. Lipolysis, proteolysis and glycolysis are the major biochemical processes in cheese during storage and ripening, which determine the characteristics and composition of the final products (González-Olivares et al., 2014; Murtaza et al., 2014; Arenas et al., 2015). These followed by breakdown of fatty acids and amino acids, which results in the production of various secondary metabolites, including metabolites for flavor development (Murtaza et al., 2014). The rate of proteolysis as determined by the concentration of free amino acids, were found higher in cheese stored at $14^{\circ} \mathrm{C}$ than that stored at $4^{\circ} \mathrm{C}$ (González-Olivares et al., 2014).

The $\mathrm{pH}$ and titratable acidity of goat cheese can be attributed to the conversion of lactose in milk during fermentation by starter bacteria mainly produced lactic acids. The accumulation of lactic acid (as measured by total titratable acidity) in cheese curd lowered the $\mathrm{pH}$. In the present study, the $\mathrm{pH}$ of fresh goat cheese was 4.6 and increased to 4.9 after 90 days of storage. Cheese $\mathrm{pH}$ is generally higher than other fermented milk products, and this condition is more favorable for probiotic bacteria (GonzálezOlivares et al., 2014).

This study incorporated starter culture of two probiotic bacteria Lactobacillus casei and Bifidobacteria longum during goat cheese manufacture. Results showed that the fresh goat cheese contained total lactic acid bacteria of $8.42 \mathrm{log} \mathrm{CFU} / \mathrm{g}$, which decreased to $7.92 \mathrm{log}$ $\mathrm{CFU} / \mathrm{g}$ and $7.46 \mathrm{log} \mathrm{CFU} / \mathrm{g}$ after 90 days of storage under high and low temperatures, respectively. Storage conditions influenced the viability of the two probiotic bacteria. It was in line with González-Olivares et al. (2014), that storage temperatures influenced the survivability of probiotic bacteria. The population density of $L$ bulgaricus 2771 and $L$ 
Juni Sumarmono et al/Animal Production. 21(1):56-63, 2019

Accredited by Kemenristek Dikti No 32a/E/KPT/2017. ISSN 1411-2027

rhamnosus GG were found higher in cheese stored at $14^{\circ} \mathrm{C}$ than that stored at $4^{\circ} \mathrm{C}$. The total lactic acid bacteria in the present study was in accordance with Oliveira et al. (2012) that lactic acid bacteria population in cheeses were above $10^{7} \mathrm{CFU} / \mathrm{g}$ during storage. However, Ong and Shah (2009) reported that different ripening temperatures did not affect probiotic population.

The viability of probiotic bacteria during processing and storage is very important for developing probiotic-containing cheese. Furthermore, the probiotic bacteria should be able to survive in the acidic the gastrointestinal conditions, including low $\mathrm{pH}$ and hydrolytic enzymes. Overall, cheeses are suitable as probiotic-containing food product due to relatively high $\mathrm{pH}$, high buffering capacity, solid consistency, and contain high fat that protects probiotics during storage and passage through the gastrointestinal tracts (Plessas et al., 2012). The present study demonstrated that probioticcontaining goat cheese can be stored up to 90 days at both low and high temperature with population of probiotics higher than $10^{7} \mathrm{CFU} / \mathrm{g}$. Previously, Setyawardani et al. (2017) reported that goat cheese containing a mixed indigenous probiotic cultures can be stored up to 30 days at $5^{\circ} \mathrm{C}$. Although total count of lactic acid bacteria may well indicate the viability of the probiotic bacteria, lack of individual counts is the limitation of the present study.

Goat cheese composition was affected by storage time, and to a lesser extent, by storage temperature. The present study produced fresh goat cheese with $56.96 \%$ moisture, 15.98 protein, $22.03 \%$ fat, and $2.5 \%$ minerals. Previous report showed different goat cheese composition, namely $62.5 \%$ moisture, $14.7 \%$ protein, $16,9 \%$ fat, and $3.97 \%$ minerals (Hayaloglu et al., 2013). The differences could be addressed to the different processing procedures and raw materials. The changes in goat cheese composition during storage could be mainly attributed to the dehydration during storage, which reduced moisture content and increased of protein, fat and mineral. Further study is needed to investigate the nutrients and metabolites contents, such as fatty acids and amino acids, as well as the textural properties of the probiotic-containing goat cheese.

\section{Conclusion}

Storage time and temperatures contribute to the variation of characteristics and composition of probiotic-containing goat cheese. The probiotic lactic acid bacteria (Lactobacillus casei and Bifidobacterium longum) were found viable in goat cheese stored at either high $\left(13-15^{\circ} \mathrm{C}\right)$ or low $\left(8-10^{\circ} \mathrm{C}\right)$ temperature for up to 90 days. Storing probiotic containing goat cheese at low temperature $\left(8-10^{\circ} \mathrm{C}\right)$ is more advantageous to prevent the presence of molds.

\section{References}

AOAC [Association of Official Analytical Chemists]. 2006. Official Method of Analysis. $15^{\text {th }}$ Ed. Association of Official Analytical Chemists Inc., Virginia USA.

Arenas, R, L González, N Sacristán, ME Tornadijo, and JM Fresno. 2015. Compositional and biochemical changes in Genestoso cheese, a Spanish raw cow's milk variety, during ripening. Journal of the Science of Food and Agriculture 95(4):851-859. doi: https://doi.org/10.1002/jsfa.7011

Bezerra, TKA, NMdO Arcanjo, ARRd Araújo, ALMd Queiroz, MEGd Oliveira, AMP Gomes, and MS Madruga. 2017. Volatile profile in goat coalho cheese supplemented with probiotic lactic acid bacteria. LWT - Food Science and Technology 76:209-215. doi: https://doi.org/10.1016/j.Iwt.2016.03.041

Burns, P, F Patrignani, D Serrazanetti, G Vinderola, J Reinheimer, R Lanciotti, and M Guerzoni. 2008. Probiotic Crescenza cheese containing Lactobacillus casei and Lactobacillus acidophilus manufactured with high-pressure homogenized milk. Journal of Dairy Science 91(2):500-512. doi: https://doi.org/10.3168/jds.2007-0516

Dantas, AB, VF Jesus, R Silva, CN Almada, E Esmerino, LP Cappato, MC Silva, RS Raices, RN Cavalcanti, and CC Carvalho. 2016. Manufacture of probiotic Minas Frescal cheese with Lactobacillus casei Zhang. Journal of Dairy Science 99(1):18-30. doi: https://doi.org/10.3168/ids.2015-9880 
Juni Sumarmono et al/Animal Production. 21(1):56-63, 2019

Accredited by Kemenristek Dikti No 32a/E/KPT/2017. ISSN 1411-2027

dos Santos, KM, MA Bomfim, AD Vieira, SD Benevides, SM Saad, FC Buriti, and AS Egito. 2012. Probiotic caprine Coalho cheese naturally enriched in conjugated linoleic acid as a vehicle for Lactobacillus acidophilus and beneficial fatty acids. International Dairy Journal 24(2):107-112. doi: https://doi.org/10.1016/j.idairyi.2011.12.001

Egger, L, and O Ménard. 2017. Update on bioactive peptides after milk and cheese digestion. Current Opinion in Food Science 14:116-121. doi: https://doi.org/10.1016/i.cofs.2017.03.003

El Galiou, O, S Zantar, M Bakkali, A Laglaoui, JA Centeno, and J Carballo. 2015. Chemical and microbiological characteristics of traditional homemade fresh goat cheeses from Northern Morocco. Small Ruminant Research 129:108-113. doi:

https://doi.org/10.1016/i.smallrumres.2015.06.0 05

González-Olivares, L, Z López-Cuellar, J AñorveMorga, M Franco-Fernández, A CastañedaOvando, E Contreras-López, J Jaimez-Ordaz, and G Rodríguez-Serrano. 2014. Viability and Proteolytic Capacity of Lactobacillus bulgaricus 2772 and Lactobacillus rhamnosus GG during cheese ripening. The Journal of Bioscience and Medicine 2014:7-12.

doi: http://dx.doi.org/10.4236/ibm.2014.23002

Hayaloglu, A, C Tolu, and K Yasar. 2013. Influence of goat breeds and starter culture systems on gross composition and proteolysis in Gokceada goat cheese during ripening. Small Ruminant Research 113(1):231-238.

Johnson, M, and B Law. 2010. The origins, development and basic operations of cheesemaking technology. In: BA Law and AY Tamime, editors, Technology of cheesemaking. Wiley-Blackwell, lowa, USA. p. 68-96.

Kumar, H, D Yadav, N Kumar, R Seth, and AK Goyal. 2016. Nutritional and nutraceutical properties of goat milk A review. Indian J Dairy Sci 69(5):513518.

Murtaza, MA, S Ur-Rehman, FM Anjum, N Huma, and I Hafiz. 2014. Cheddar cheese ripening and flavor characterization: a review. Critical Reviews in Food Science and Nutrition 54(10):1309-1321. doi:

https://doi.org/10.1080/10408398.2011.634531

Nongonierma, $A B$, and RJ FitzGerald. 2015. The scientific evidence for the role of milk proteinderived bioactive peptides in humans: A Review. Journal of functional foods 17:640-656. doi: https://doi.org/10.1016/i.jff.2015.06.021

Oliveira, MEGd, EF Garcia, RdCRd Queiroga, and ELd Souza. 2012. Technological, physicochemical and sensory characteristics of a Brazilian semi-hard goat cheese (coalho) with added probiotic lactic acid bacteria. Scientia Agricola 69(6):370-379. doi: http://dx.doi.org/10.1590/S0103$\underline{90162012000600005}$

Ong, L, and NP Shah. 2009. Probiotic Cheddar cheese: Influence of ripening temperatures on survival of probiotic microorganisms, cheese composition and organic acid profiles. LWT-Food Science and Technology 42(7):1260-1268. doi: https://doi.org/10.1016/j.lwt.2009.01.011

Park, YW, and MS Nam. 2015. Bioactive peptides in milk and dairy products: a review. Korean Journal for Food Science of Animal Resources 35(6):831840. doi: https://dx.doi.org/10.5851\%2Fkosfa.2015.35.6.8 $\underline{31}$

Plessas, S, L Bosnea, A Alexopoulos, and E Bezirtzoglou. 2012. Potential effects of probiotics in cheese and yogurt production: A review. Engineering in Life Sciences 12(4):433-440. doi: https://doi.org/10.1002/elsc.201100122

Santiago-López, L, JE Aguilar-Toalá, A HernándezMendoza, B Vallejo-Cordoba, AM Liceaga, and AF González-Córdova. 2018. Invited review: Bioactive compounds produced during cheese ripening and health effects associated with aged cheese consumption. Journal of Dairy Science 101(5):3742-3757. doi: https://doi.org/10.3168/ids.2017-13465

Setyawardani, T, AHD Rahardjo, and M Sulistyowati. 2017. Chemical Characteristics of Goat Cheese with Different Percentages of Mixed Indigenous Probiotic Culture during Ripening. Media Peternakan 40(1):55-62. doi: https://doi.org/10.5398/medpet.2017.40.1.55

Setyawardani, T, and J Sumarmono. 2015. Chemical and Microbiological Characteristics of Goat Milk Kefir During Storage Under Different Temperatures. Journal of the Indonesian Tropical Animal Agriculture 40(3):183-188. doi: https://doi.org/10.14710/jitaa.40.3.183-188

Shiby, V, and H Mishra. 2013. Fermented milks and milk products as functional foods-a review. Critical Reviews in Food Science and Nutrition 53(5):482-496.

doi: https://doi.org/10.1080/10408398.2010.547398

Sumarmono, J, M Sulistyowati, and Soenarto. 2015. Fatty Acids Profiles of Fresh Milk, Yogurt and Concentrated Yogurt from Peranakan Etawah 
Juni Sumarmono et al/Animal Production. 21(1):56-63, 2019

Accredited by Kemenristek Dikti No 32a/E/KPT/2017. ISSN 1411-2027

Goat Milk. Procedia of Food Science

3(Elsevier):216-222. doi:

https://doi.org/10.1016/i.profoo.2015.01.024 